19 Revue d'histoire du XIXe siècle

Société d'histoire de la révolution de 1848 et des

révolutions du XIXe siècle

12 | 1996

L'incendie

\title{
Hommage à Philippe Vigier (1924-1995)
}

Alain Corbin

OpenEdition

Journals

Electronic version

URL: http://journals.openedition.org/rh19/89

DOI: $10.4000 /$ rh 19.89

ISSN: $1777-5329$

Publisher

La Société de 1848

Printed version

Date of publication: 1 June 1996

ISSN: 1265-1354

Electronic reference

Alain Corbin, « Hommage à Philippe Vigier (1924-1995) », Revue d'histoire du XIXe siècle [Online], 12 |

1996, Online since, connection on 19 September 2020. URL : http://journals.openedition.org/rh19/89 ; DOI : https://doi.org/10.4000/rh19.89

This text was automatically generated on 19 September 2020

Tous droits réservés 


\title{
Hommage à Philippe Vigier (1924-1995)
}

\author{
Alain Corbin
}

\section{ABSTRACTS}

No abstract available by now

Pas de résumé disponible actuellement

INDEX

Mots-clés: Hommage, Vigier Philippe 